\title{
MISCELLANEA
}

\section{Вадим АРІСТОВ}

кандидат історичних наук, старший науковий співробітник, Інститут історії України НАН України; науковий співробітник,

Національний музей історії України

(Київ, Україна), aristov3000@ukr.net

ORCID: https://orcid.org/0000-0002-3094-8850

\section{Коли місто Козелець отримало магдебурзьке право?*}

УДК: 94(477)

\begin{abstract}
Анотація. Дата й обставини отримання Козельцем магдебурзького права досі були предметом дискусії. Суперечки спиралися на два документи: універсал гетьмана Б.Хмельницького 1656 р. про звільнення козелецьких міщан від низки повинностей і привілей короля Яна Казимира 1663 р. Проте головний документ - перша жалувана грамота - не був відомий у науці й залишався неопублікованим. Стаття заповнює цю археографічну лакуну. У фондах Національного музею історії України зберігається грамота царя Олексія Михайловича 1655 р., який надав міщанам Козельця магдебурзьке право. Текст акта, а також супровідного аркушу, що був доданий після 1667 р., публікується у цій статті, що дозволяє відновити історію отримання Козельцем міських прав. Другим відомим документом козелецького самоврядування став універсал Б.Хмельницького 1656 р. Улітку 1663 р. недоторканність прав міщан підтвердив гетьман І.Брюховецький. Невдовзі грамота Олексія Михайловича була вивезена з Козельця королем Яном Казимиром під час походу на Лівобережжя України в 1663-1664 рр. Натомість він видав новий привілей від власного імені. На прикладі документів 1655-1663 рр., пов'язаних з утвердженням у Козельці магдебурзького права, можна простежити, як формувалися міські перекази про «давні права». Верхівка міщан Козельця на чолі з О.Долинським швидко «винайшла» традицію про те, що «права і свободи» надали місту «давні» польські королі. За іронією долі, справжнє надання привілею польським королем поклало кінець цій традиції.
\end{abstract}

Ключові слова: Козелець, магдебурзьке право, Національний музей історії України, Олексій Михайлович, Богдан Хмельницький, Іван Брюховецький, Іван Виговський, Ян Казимир.

У науковій і популярній літературі існують дві відповіді на винесене у заголовок запитання. Вони спираються на два документи. Згідно з однією версією, надання

\footnotetext{
* Статтю підготовлено в рамках наукової теми «Києво-руська та литовсько-польська спадщина в політичних і соціокультурних практиках ранньомодерної України: дискурси традиціоналізму та новаторства», яка виконується в Інституті історії України НАН України в 2020-2021 рр.
} 
Козельцю магдебурзького права ${ }^{1}$ відбулося 1656 р. за універсалом Б.Хмельницького ${ }^{2}$ Згідно з іншою, це сталося 1663 р. - за універсалом короля Яна Казимира під час походу на Лівобережжя України ${ }^{3}$.

Перша версія спирається на гетьманський універсал від 10 жовтня 1656 р. ${ }^{4}$ У документі йшлося про звільнення козелецьких міщан від низки стягнень і повинностей («возовоє», «помірноє», «деготь», «воскобуйню», «поведерщину»). Прибутки мали залишатися в міщан та йти, зокрема, на «побудованє ратуша». Згадка ратуші, хай навіть тільки запроектованої чи недобудованої, а також (у санкції грамоти) «міщан і ратушних міста Козельця», указує на те, що поселення вже мало самоврядування. Жодного слова про надання «прав і привілеїв» в універсалі немає. Зрештою, гетьман не мав повноважень для видання такої грамоти. Це мав зробити верховний суверен.

Підставою для другої версії служить грамота Яна Казимира, видана в м. Остер 29 грудня 1663 р., про надання Козельцю магдебурзького права 5 Це розлогий документ, що пояснює умови видання (похід короля на Лівобережжя і спроба відвоювати «загарбані провінції»), а також розкриває зміст прав, які надавалися міщанам (зокрема коротко описує устрій «магдебурзького» міста). Грамота містить список осіб, що зверталися до короля як представники міської громади із проханням надати місту права: Олександр Іванович Долинський, Самуїл Брилевич, Тимофій Юркович, Григорій Василевич, Карп Колесникович, Василь Коропко, Юрій Іванович, Павло Грига, Данило Миропольський, Семен Лопух, Іван Борсук, Іван Чамарний, Трохим Яцкевич, Петро Сезонович

Текст привілею побудовано так, щоб створити враження, ніби магдебурзьке право надається Козельцю вперше. Однак документ «проговорюється», указує на вже наявні елементи самоврядування, а саме - ратуші: «сhса̨с, aby na poprawę miasta, ratusza, drog, bram, baszt, parkanów iakąkolwiek intratę mieli, pozwalamy pod ratuszem $i$ około ratusza mieć powedersczyznę, wagę dla ważenia towarów wszelkich pomierne, postrzygalnię, wojskobojnię» ${ }^{7}$. У цьому уривку можемо побачити ті самі повинності, від сплати яких козельчани звільнялися універсалом Б.Хмельницького: «powedersczyznę [...] pomierne, [...] wojskobojnię». Так само йдеться тут про «роprawę» тієї ратуші, будівництво якої згадувалося в гетьманському акті. Вочевидь, королівський привілей не надавав місту магдебурзьке право вперше, а тільки утверджував його. Але чому тоді документ не покликається до попередників Яна Казимира, які 6 могли це право надати, і не згадує жодні попередні грамоти? Відповідь може полягати в тому, що міщани отримали перший привілей не від польських королів, а від їхніх супротивників. А отже, будь-які видані ними документи коронна адміністрація вважала нелегітимними.

Так насправді й було. Ще наприкінці XIX ст. опубліковано чолобитну міщан Козельця про надання місту магдебурзького права, подану цареві Олексієві Михайловичу 2 серпня 1655 р. ${ }^{8}$ Текст склали «войтъ Александръ Долинской съ

\footnotetext{
1 Про особливості магдебурзького права в містах Лівобережної України див.: Багалей Д. Магдебургское право в Левобережной Малороссии // Журнал Министерства народного просвещения. - Ч.280. - Март, 1892. - Санкт-Петербург, 1892. - С.1-55.

2 Історія міст і сіл Української РСР в двадцяти шести томах: Чернігівська обл. - К., 1972. - С.302.

3 Мицик Ю.А. Хто і коли надав магдебурзьке право Козельцю і Остру // Сіверянський літопис. - Вип.6. - Чернігів, 2019. - С.64-69.

4 Акты, относящиеся к истории Южной и Западной России (далі - АЮЗР). - Т.3: 1638-1657. - Санкт- Петербург, 1861. - С.548-549 (№363); Документи Богдана Хмельницького (1648-1657). - К., 1961. - С.539-540 (№412).

5 Руська (Волинська) Метрика: Книга за 1652-1673 рр. - Острог; Варшава; Москва, 1999. - С.353-359 (№133).

6 Там само. - С.356. У польському тексті: «[...] na suplikę sławetnych Alexandra Iwanowicza Dolińskiego, Samuela Brylewicza, Tymofiia Iurkowicza, Hrehorego Wasilewicza, Karpia Kolesnikowicza, Wasila Koropka, Ierzego Iwanowicza, Pawła Grygi, Daniła Miropolskiego, Semena Łopucha, Iwana Borsuka, Iwana Czamarnego, Trochima Iackiewicza, Piotra Sezonowicza».

Там само.

АЮЗР. - Т.14. - Санкт- Петербург, 1889. - С.781-782.
} 
товарыщи» ${ }^{9}$ Крім документа від імені міщан, царю було надано листа від гетьмана Б.Хмельницького, котрий просив, «чтобъ великий государь его царское величество ихъ козелцовъ пожаловалъ права и привилья и свободы и всякие добра которые издавна наданые вельлъ подкрђпити навЂки своею государскою жаловалною грамотою» ${ }^{10}$.

Безпосереднім приводом подання козельчанами чолобитної, найвірогідніше, стала спроба І.Виговського (на той час - гетьманського писаря) закріпити Козелець як своє володіння. Невдовзі після переходу Війська Запорозького «з містами й землями» в підданство московського царя, І.Виговський поспішив використати нового сюзерена для суттєвого збільшення своїх (і своєї родини) маєтностей. Улітку 1654 р. його брат Данило їздив до Москви з клопотанням до царя про жалувану грамоту членам родини Виговських. У серпні 1654 р. Олексій Михайлович видав таку грамоту Іванові Виговському на володіння низкою сіл, угідь, міст і містечок, зокрема Козельцем ${ }^{11}$.

Слід гадати, підлеглість новоявленому панові була обтяжливою для козельчан i спонукала бити чолом царю про надання їхньому місту магдебурзького права. Підтримка прохання Б.Хмельницьким може свідчити про співчуття гетьмана міщанам і небажання швидкого (тим більше, в обхід його влади) посилення власних метких урядників, найспритнішим з яких був І.Виговський. Судячи з подальших подій, клопотання міщан було задоволене.

8 липня 1663 р. гетьман І.Брюховецький видав грамоту на підтвердження магдебурзького права Козельця ${ }^{12}$. Від імені міщан звернення до нього склали «Александеръ Долинский, вуйтъ, бурмистеръ и ввесь майстратъ козелскій», тобто та сама, відома нам з попередніх документів, верхівка на чолі з О.Долинським. Гетьманові було надано наявні в міщан акти: «Грамоту великого государя нашего, его царского пресвЂтлого величества, на давніе права и свободы майдебурскіе, одъ королей полских майстратови козелскому наданніе жалованные, и при томъ иніе грамоти государскіе, тому жъ мЂсту служачие, яко и унъверсалами прошлих антецессоров нашихъ на тіе жъ права майдебурскіе козелчаномъ належніе». У цьому переліку документів непрямо згадано універсал Б.Хмельницького 1656 р. («унЊверсалами прошлих антецессоров нашихъ»). Але першою виступає «грамота великого государя».

Для повноти документальної картини становлення міського самоврядування в Козельці досі бракувало саме цього головного елемента мозаїки - жалуваної грамоти, про яку влітку 1655 р. клопоталися міщани за сприяння Б.Хмельницького. Вона зберігається у фондах Національного музею історії України (НМIУ) в колекції рукописних документів - справа РД-131 (див. док. 1).

Не можна сказати, що грамота була зовсім невідома в науці. Видавці чолобитної козелецьких міщан 1655 р. у примітці зазначили, що документ зберігався в Архіві міністерства іноземних справ у Москві, у справах малоросійських (зв'язка 11, зошит 14). У зошиті було три аркуші, з них - два документи: чолобитна та, власне, жалувана грамота. Однак опубліковано було тільки чолобитну. Про існування грамоти забули. Як наслідок, суперечки щодо запровадження магдебурзького права в Козельці спиралися на периферійні документи, оминаючи центральний.

Тепер картина відновлює цілісність. Не від універсалу Б.Хмельницького 1656 р., і не від грамоти Яна Казимира 1663 р., а від грамоти Олексія Михайловича 1655 р. треба вести історію міського самоврядування в Козельці.

\footnotetext{
Там же. - С.781.

10 Там же. - C.782.

11 Там же. - Т.10. - Санкт-Петербург, 1878. - С.671-672 (прим.); Т.15. - Санкт- Петербург, 1892. - С.1-4.

12 Універсали українських гетьманів від Івана Виговського до Івана Самойловича (1657-1687). - К.; Л., 2004. - С.289 (№188).
} 
Цей документ зберігався в місті до 1663 р., що засвідчує його згадка у грамоті І.Брюховецького. Але дуже скоро він виїхав звідси назавжди. Про це розповідає текст на паперовому аркуші, що зберігся у фондах НМІУ в конвої жалуваної грамоти (РД-131). Це є той таємничий «третій аркуш» із зошиту, де містилася чолобитна козельчан і жалувана грамота 1655 р. Свого часу видавці 14-го тому «АЮЗР» його змісту не розкрили. Зараз цю археографічну прогалину можна заповнити.

Напис на аркуші, зроблений польською мовою, сповіщає про те, що під час походу за Дніпро в 1664 р. король Ян Казимир забрав грамоту, видану Олексієм Михайловичем, після того, як козельчани зреклися «московської протекції» (див. док. 2). Цю приписку до жалуваної грамоти було зроблено невдовзі («teraz») після 1667 р. Це видно з ії заключних слів, що відзначають зміну московським царем після Андрусівського перемир'я («ро Paktach») печатки ${ }^{13}$ : «Notandum ze pieczęc inaksza była przed Paktami Anni 1667 A inakszey teraz po Paktach zazywa».

Найвірогідніше, грамота Олексія Михайловича була віддана Янові Казимиру ще наприкінці грудня 1663 р., і цю подію треба напряму пов’язувати з виданням нового привілею Козельцю на магдебурзьке право 29 грудня того року. Натомість у польській приписці датування видається неточним - iï автор орієнтувався на час закінчення задніпровської кампанії й повернення короля на Правобережжя в лютому - березні 1664 р. Після 1667 р. жалувана грамота московського царя місту Козельцю перебувала в Короні Польській. Коли ж вона потрапила до Росії, зокрема до Архіву міністерства іноземних справ, - питання поки що залишається відкритим.

На прикладі розглянутих вище документів можна простежити, як формувався фіктивний образ «давніх прав» Козельця, як «новина» ставала «стариною»14. Міщани отримували привілей на магдебурзьке право вперше, проте намагалися подовжити історію своїх прав на самоврядування. У цьому полягала особливість цього випадку, що добре видно на порівнянні з іншими «містами з історією».

У 1654 р. у зверненні до царя міщани Переяслава просили про підтвердження «правъ и привиліевъ нашихъ, намъ отъ давныхъ королей полскихъ наданыхъ» ${ }^{15}$. I справді, вони подали наявні документи, що засвідчували права на самоврядування, зокрема привілеї Сигізмунда III та Владислава IV $^{16}$. Так само набір власних привілеїв від великих князів литовських і королів польських подали цареві міщани Києва, звертаючись до нього з аналогічним клопотанням ${ }^{17}$. Натомість козельчани не мали жодних документів від попередніх державців. А тому у чолобитній їм довелося майстерно доводити своє «право на право».

Спершу в тексті пояснювалося походження козелецьких міщан, така собі «етногенетична легенда»: «Мы убогие граждане мЂста Козелца будучи извоеванные чрезъ ть льта войною сошли есмя до новосаженого города Козелца уходя отъ Ляховъ чтобъ есмя при вЂрђ своей православной были а имянно изо Львова съ Премышля изъ Острога съ Костянтинова и Каменца Подолского и изъ иныхъ разныхъ мҺстъ» ${ }^{18}$.

\footnotetext{
13 Про нову державну печатку царя, створену після Андрусівського перемир'я, див.: Пчелов Е.В. Государственная печать Алексея Михайловича 1667 г.: К 350-летию герба Московского царства // Вестник архивиста. - 2017. - №4. - С.147-158.

14 Про категорію «старовини» в пізньосередньовічній і ранньомодерній Україні див.: Кром М.M. «Старина» как категория средневекового менталитета: по материалам великого княжества Литовского 14 - нач. 17 вв. // Mediaevalia Ucrainica. - Т.3. - К., 1994. C.68-85.

15 AЮ3Р. - T.10. - C.516.

16 Там же. - С.517-532.

17 Там же. - С.615-644.

18 Там же. - T.14. - C.781.
} 
Далі йшло обгрунтування потреби козельчан у жалуваній грамоті: «Чтобъ есмя по привилью нашему судилися правомъ магдебургскимъ въ ратушђ какъ есмя издавна навыкли» ${ }^{19}$. Тобто свою «звичку» до магдебурзького права козелецькі міщани нібито набули до втечі, коли вони або їхні предки ще жили в інших містах і там цим правом керувалися.

Чи то аргументи козельчан виявилися переконливими, чи то царська адміністрація не схотіла розбиратися в тонкощах і вжила звичне кліше, але у грамоті Олексія Михайловича бачимо таке формулювання: «Права привилия и свободы и всякие добра которые от велики(х) бл(а)гоч(ес)т(и)выхъ кн(я)зе(и) и короле(и) по(л)скихъ наданые». Зрозуміло, що укладачі документа не мали на увазі конкретних правителів та їхні грамоти (яких не існувало), а в особі абстрактних «князів і королів» апелювали до минулого загалом. Текст створював враження, що в міщан Козельця вже були «привілеї та свободи», надані попередніми володарями, а цар лише відновлював/підтверджував їх і гарантував недоторканність.

Нарешті, в універсалі І.Брюховецького 1663 р. спостерігаємо вже сформовану фікцію: «Давніе права и свободы майдебурскіе, одъ королей полских майстратови козелскому наданніе жалованные» ${ }^{20}$. Як бачимо, у тексті спеціально уточнено, що магдебурзькі «права і свободи» польські королі надавали саме «козелецькому магістрату». Минуло лише вісім років - і «традицію» було «винайдено».

Проте короткочасний перехід Козельця в руки польського короля анулював цю традицію. Міське самоврядування було ніби перезасновано, місто отримало печатку (велику й малу) та герб («chorągiew miejska») $)^{21}$, що залишалися в ужитку після повернення під владу Війська Запорозького. Щойно вигадана легенда про давні початки магдебурзького права Козельця («права и свободы майдебурскіе, одъ королей полских майстратови козелскому наданніе»), як виявилося, стала передбаченням недалекого майбутнього: наприкінці 1663 р. польський король справді надав козелецькому магістратові права та свободи. Натомість у минуле пішли перші вісім років самоврядування Козельця й жалувана грамота 1655 р.

Матеріали зберігаються в Національному музеї історії України (фондова колекція «Рукописні документи», спр.131). При їх публікації збережено оригінальну орфографію рукопису, виносні літери подано у круглих дужках.

\section{№1}

\section{Грамота царя Олексія Михайловича міщанам Козельця від 5 серпня 1655 р.}

Б(о)жиею м(и)л(ос)тию мы вел(и)киі г(осу)д(а)рь ц(а)рь і великиі кн(я)зь Алексь(и) Михаиловичь всеа Великия і Малыя Росиі самодержецъ Московскиі Киевскиі Владимерскиі Новгородцкиі ц(а)рь Казанскиі ц(а)рь Астраханскиі ц(а)рь Сибирскиі г(осу)д(а)рь Псковскиі великиі кн(я)зь Смоленскиі Тверскиі Югорскиі Пермскиі Вятцкиі Болгарскиі і иныхъ, г(осу)д(а)рь i великиі кн(я)зь Новагорода Низовские земли Черниговскиі Резански Полотцкиі Ростовскиі

\footnotetext{
19 Там же.

20 Універсали українських гетьманів від Івана Виговського до Івана Самойловича (1657-1687). - С.289 (№188).

${ }^{21}$ Руська (Волинська) Метрика: Книга за 1652-1673 рр. - С.358.
} 
Яросла(в)скиі Белозерскиі Удорскиі О(б)дорскиі Кондинскиі Витебскиі Мстиславскиі і всеа сьверныя страны повелитель, і г(осу)д(а)рь Иверские земли Карталиискихъ и Грузинскихъ ц(а)ре(и) і Кабардинские земли Черкаскихъ і Горскихъ кн(я)зеи і ины(мъ) многимъ г(осу)д(а)р(с)твамъ и землямъ восточнымъ и западнымъ і съвернымъ отчичь и дЂдичь и насльдникъ и г(осу)д(а)рь и облаадатель.

Пожаловали есмя н(а)ш(е)го ц(а)рского величества города Козе(л)ца мещанъ въ н(ы)нешне(м) во 163 году августа въ 2 (день). Подали они намъ великому г(осу)д(а)рю нашего ц(а)рского величества Во(и)ска Запорожского Гетмана Богдана Хме(л)ницкого листъ, а в томъ листу написано, бьетъ челомъ на(м) великому г(осу)д(а)рю н(а)шему ц(а)рскому величеству он Гетман чтоб намъ великому г(осу)д(а)рю пожаловати тьхъ козелецкихъ мещанъ права привилия і свободы і всякие добра которые от велики(х) бл(а)гоч(ес)т(и)выхъ кн(я)зе(и) і короле(и) по(л)скихъ наданые вельти по(д)твердити на веки потом дати имъ н(а)шу ц(а)рского величества жаловалную грамоту.

И мы великиі г(осу)д(а)рь ц(а)рь і великиі кн(я)зь Алексъ(и) Михаиловичь всеа Великия і Малыя Росиі самодержець н(а)ш(е)го ц(а)рского величества города Козе(л)ца меща(н) пожаловали права и привилия которые от велики(х) бл(а)гоч(ес)т(и)вы(хъ) кн(я)зе(и) і короле(и) по(л)скихъ даны нарушити не вельли и ме(ж) себя во(и)та і бурмистровъ і ра(и)цовъ і лавниковъ выбирати имъ поволили, и на пре(ж)ние ихъ привилия велБли и(м) дати сю н(а)шу ц(а)рского величества жаловалную грамоту за н(а)шею г(осу)д(а)рскою печатью.

И имъ н(a)ш(е)го ц(а)рского величества города Козе(л)ца мещаномъ видя к себъ н(а)шу г(осу)д(а)рскую премногую м(и)л(о)сть и жалованье намъ великому г(осу)д(а)рю н(а)ш(е)му ц(а)рскому величеству и с(ы)ну н(а)ш(е)го ц(а)рского величества бл(а)говЂрному ц(а)р(е)в(и)чю и великому кн(я)зю Алексъю Алексђевичю всеа Великия и Малыя Росиі служити і прямити і всякого добра хотЂти во все(м) на чемъ они намъ великому г(осу)д(а)рю н(а)ш(е)му ц(а)рскому величеству по св(я)то(и) і непорочно(и) ева(н)гельско(и) заповеди вЂру учинили,

Дана ся н(а)ша ц(а)рского величества жаловалная грамота в н(а)ш(е)мъ г(осу)д(а)рскомъ походе на стану в н(а)ш(е)мъ ц(а)рского величества городе Ви(л)не льта 7163 августа въ 5 (день).

\section{№2}

\section{Приписка про грамоту Олексія Михайловича на окремому аркуші}

Prziwiley Cara Moskiewskiego miastu Kozielcu za Dnieprem, na instancią Bogdana Chmielnickiego dany. A pod bytnosc Krola J(ego)M(os)ci Jana Kazimirza za Dnieprem po odebranych z rąk Moskiewskich wielu miast przeß mieszczan Kozieleckich przy wyrzecßeniu się Protectiey Moskiewskiey temuz Krolowi Je(go)M(os)ci oddany A(n)no D(omi)ni 1664

Notandum ze pieczęc inaksza była przed Paktami

Anni 1667 A inakszey teraz po Paktach zazywa

\section{REFERENCES}

1. Krom, M. (1994). «Starina» kak kategoriya srednevekovogo mentaliteta: po materialam Velikogo kniazhestva Litovskogo 14 - nach. 17 vv. Mediaevalia Ucrainica, 3. Kiev. [in Russian].

2. Mytsyk, Yu. (2019). Khto i koly nadav mahdeburzke pravo Kozeltsiu i Ostru. Siverianskyi litopys, 6. Chernihiv. [in Ukrainian].

3. Pchelov, Ye. (2017). Gosudarstvennaya pechat Alekseia Mikhaylovicha 1667 g.: K 350-letiyu gerba Moskovskogo tsarstva. Vestnik arkhivista, 4. [in Russian]. 


\author{
Vadym ARISTOV \\ Candidate of Historical Sciences (Ph. D. in History), Senior Research Fellow, \\ Institute of History of Ukraine NAS of Ukraine; \\ Research Fellow, \\ National Museum of the History of Ukraine \\ (Kyiv, Ukraine), aristov3000@ukr.net \\ ORCID: https://orcid.org/0000-0002-3094-8850
}

\title{
When did Kozelets Receive the Magdeburg Law?
}

\begin{abstract}
The date and circumstances of Kozelets's acquisition of Magdeburg law have so far been the subject of debate. Disputes over the introduction of Magdeburg law in Kozelets were based on two documents: the universal of Hetman B.Khmelnytskyi (1656) on the release of Kozelets citizens from a number of duties and the letters patent of King John Casimir (1663). However, the main document - the first letters patent - was not known in the scholarship and remained unpublished. The article fills this archeographic gap. The funds of the National Museum of Ukrainian History contain a diploma of Tsar Oleksiy Mykhailovych of 1655, who granted the townspeople of Kozelets the Magdeburg law. The text of the diploma, as well as the accompanying sheet, which was added after 1667, is published in this article. Taking into account this document it is possible to reconstruct the history of how Kozelets obtained city rights. In 1655 the citizens submitted a petition to the tsar for a letters patent. Their request was granted and a diploma was issued, which is now in the National Museum of the History of Ukraine. It is probable that the petition of the citizens to the Tsar was caused by the activity of I.Vyhovskyi, who in 1654 received from Aleksey Mikhailovich the right to possession of a number of villages, towns and cities. One of them was Kozelets. The second known document in the history of Kozelets self-government was the universal of Hetman B.Khmelnytskyi (1656). In the summer of 1663, the inviolability of the rights of the citizens of Kozelets was confirmed by Hetman I.Briukhovetskyi. Soon Aleksey Mikhailovich's diploma was taken out of Kozelets by the King John Casimir during the campaign to the Left-Bank Ukraine in 1663-1664. Instead, the king issued a new letters patent on his own behalf. On the example of the documents of 1655-1663, connected to the establishment of Magdeburg law in Kozelets, it is possible to trace how the city legends about "old rights" were formed. The top citizens of Kozelets, led by O.Dolynskyi, quickly "invented" the tradition about the "rights and freedoms" given to the city by "old" Polish kings. Ironically, the real granting of the letters patent by the Polish king put an end to this tradition.
\end{abstract}

Keywords: Kozelets, Magdeburg law, National Museum of the History of Ukraine, Aleksey Mikhailovich, Bohdan Khmelnytskyi, Ivan Briukhovetskyi, Ivan Vyhovskyi, John Casimir. 